\title{
Contrastive Analysis of German and Malay Modal Verbs
}

\author{
Farhana Muslim Mohd Jalis ${ }^{1} \&$ Normaliza Abd Rahim ${ }^{1}$ \\ ${ }^{1}$ Faculty of Modern Languages and Communication, Universiti Putra Malaysia, Malaysia \\ Correspondence: Farhana Muslim Mohd Jalis, Faculty of Modern Languages and Communication, Universiti \\ Putra Malaysia, Malaysia. E-mail: farhana.mjalis@gmail.com
}

\author{
Received: October 24, 2013 Accepted: January 15, 2014 Online Published: February 26, 2014 \\ doi:10.5539/ass.v10n6p81 \\ URL: http://dx.doi.org/10.5539/ass.v10n6p81
}

\begin{abstract}
This study focuses on the contrastive analysis of German and Malay modal verbs. It aims to contrast the similarities and differences of German modal verb word formation process to Malay (Kata Bantu Ragam) by using Whitman's Model (1970). This qualitative study of contrast modal verbs occurred in the editorial column of Kuala Lumpur German speaking society's magazine "KL-POST" issued in the year of 2012 which served as research instrument. The method also includes content analysis which the data will be identified, underlined, translated and gathered before explicitly contrast and discussed. This contrastive study of German and Malay modal verbs will have implication on both learning and teaching of German. It may provide better understanding for new learners of German to form German sentences thus resulting in less error in their studies. This study may be used not only by students, but also language instructors and lectures who will apply this study as a guide to prepare a better teaching plan in order to provide better explanations when dealing with learners who are morphologically and semantically incompetent.
\end{abstract}

Keywords: contrastive analysis, conjugation, verb placement, mood, modals

\section{Introduction}

The year 1958 marks a new era of learning German officially in Malaysia with the first establishment of Goethe Institute in Penang. Since then, there have been many foreign relations made between Malaysia and Germany as well as other agencies with various purposes such as education, cultural exchange and business. Knowing the importance of keeping this relation, the Malaysian government has been encouraging Malaysians to learn German. Acquiring a foreign language is not an easy task especially when the target language has a lot of differences in its grammatical system. According to Kendris (2007, p. 1), "Verbs have always been a major problem for students no matter what system or approach the teacher uses". Learning German verbs will also appear as a challenge for Malaysian language learners due to the typological differences, Koh (2009, p. 54). Since the amount of study in contrasting German and Malay is still small, there has been very little academic discussion in solving the issues of German grammar acquisition among Malaysian learners. When constructing German modal verb in a phrase, disoriented Malaysian learners may face many challenges due to the word formation process differences, Schmitz (1991). The function of modal verb is very important because modal verb expresses the possibility or obligation, Biber et al. (2004, p. 176). Therefore if a modal verb is not translated or used properly, it could lead to misunderstanding of a whole sentence meaning, Hasmidar Hassan (2009, p. 501). More often they use source language as a guide to form German sentences and these would lead to errors, Schmitz (1991). Many Malaysian learners of German only learn German based on grammar books and explanation from their educator in classes, Koh (2009, p. 99). Even worst, lack of reading material and German-Malay or Malay-German dictionaries may worsen the situation, Diederich (2003). Therefore, this study is hoped to provide an alternative way of explaining to the new learners of German in order to understand German language better.

\section{The Contrastive Analysis in Cross Linguistics Studies}

Contrastive Analysis (CA) is defined as a sub discipline of linguistics concerning with comparing a set of two languages to obtain the similarities and differences between them (Whitman, 1970; Fisiak, 1978; James, 1980). Whitman (1970, p. 191) differs in his opinion significantly from other linguist experts such as Lee (1968) and Wardhaugh (1970) who believe that contrastive analysis cannot be used in predicting language learning problems. Meanwhile Whitman is of the view that, CA could be useful in explaining the existing difficulties as well as it 
could also provide a systematical contrastive method. This is done by preparing a model which can be used to contrast languages and make prediction of language problems. Whitman creates a CA model which has four stages of procedures. The stages are description, selection, contrast and prediction making. In the first stage, a set of two languages (L1 and L2) is taken and written the formal description of the languages. The second stage is where a form of description from both languages is being selected. The selected form will be then contrasted from L1 and L2. The 'form' in his paper is referred to any linguistics unit of any size that has been formally described. The last stage is to make a prediction of difficulty through the contrast. In making prediction, Whitman (1970) suggests two ways of doing it. The first way is by formulating a hierarchy of difficulty and second is through more direct applications of psycholinguistic theory. To describe a prediction, Stockwell et al. (1965) proposes a 'hierarchy of difficulty' based on comparing what linguistics choices the learners must take in (1) their native languages and (2) the language they are learning. Stockwell et al. (1965) distinguishes three types of choices: no choice at all, optional choice and obligatory choice. The highest level of difficulty is where learners have no choice at all in the learner's L1 but have to make an obligatory choice in L2. The lowest level of difficulty is when there is an obligatory choice available in both languages for the learners to choose from (Littlewood, 1984, p. 18). Whitman (1970) in his paper also suggests using Stockwell et al. (1965) hierarchical approach where the outcomes must be ranked and placed in the proper position in the hierarchy.

Schmitz (1991) discusses on interference problems of source language with Malay learners of German. This study uses both contrastive and error analysis. Schmitz attempts, for pedagogical purposes, compare the basic phonological, morphological and syntactical structures of Malay and German with the main focus on learning problems generated by source language interference. Schmitz (1991) uses Selinker's (1972) list of psychological process involved in language learning and used contrastive approach in his study. His objective of study is focuses on contrasting German and Malay by using student's error as a main discussion. Student often makes various types of grammatical problem when they use either Malay or English as a language base to forming German sentences. It is observed that student makes less frequent inflection error where source language subsystem has similar morphological distinction to those in target language. Schmitz (1991) uses transformational grammar model in his contrastive studies as he said it is very much followed during the 70's and the 80 's. In verb inflection, he clarifies that in Malay, the distinction between inflectional and derivational morpheme is not a clear cut. German on the other hand distinct inflection and derivational morpheme relatively clear. Though the study by Schmitz contrast most major components in German and Malay language by referring to student's error, he didn't make any prediction on level of difficulties towards the students.

Hasmidar Hassan (2009) agrees that the task of translating modal verb from one language to another carries a significant implication for the overall meaning of a text conveyed by the reader. Translating a word from a language to another is a huge task since the interpreter needs to reform a text from a source language to a target language based on its semantic structure. This article discusses about the translation of modal verb from source language to a target language in political discourse. She also uses Sperber \& Wilson (1995) Relevance Theory to show that the translator carries a huge task during translating a political discourse when analyzing this pragmatic translation data discourse. The study uses a political discourse by the Malaysian Prime Minister, Datuk Seri Najib Tun Abdul Razak. The source text is translated from English version to Malay. In political text, modal verbs can convey the meaning of obligation, power and determination of a political leader to the readers. A missed translated word of modal verbs could lead to different perception or understanding of what is the actual intention. The result from the translated text revealed that modal verbs 'must' were used 16 times and 'should' was used only once. According to Halliday (1995) and Coates (1983), the used of word 'must' has a very powerful urge consistent with the aim of the writer or the speaker (here is the Prime Minister) to show his power, integrity and obligation to the reader or listener. Some of the word 'must' is not translated accordingly to the actual Malay word which is 'harus', 'perlu' or 'dikehendaki'. Hasmidar Hassan (2009) considers the translation of Datuk Seri Najib Tun Abdul Razak's text is unsuccessful because the translation is failed to follow the cognitive relevance and communicative principle due to the fact that the translator did not assure the translation could be interpret easily by the reader.

The study made by Schmitz (1991) is definitely a good platform to start in the field of CA for German and Malay. His study looks at some of the areas of EA and CA which can be related as an interference of L1 (Malay) in learning German (L2). However, his study does not predict any level of difficulty to the existing language learning problems. This study on the other hand, attempts to narrow the problem mentioned above by focusing more on a precise topic and also to make predictions to what might cause difficulties for Malaysian learners learning German. Meanwhile in the contrastive study of Hasmidar Hassan (2009), it shows how readers may misunderstand the original speaker's intention only by mistranslate modal verbs. Although she applies 
contrastive analysis in her study, she focuses more on translation rather than examining other important elements of the problem. This study, in contrast, does not only show translation, but also uses morphology as an element of contrastive. Both studies seem to support Whitman's (1970) opinion that CA may provide an alternative solution for language learning problems. This study therefore attempts to support Whitman's (1970) opinion by doing a contrastive analysis study on German to Malay modal verbs.

\section{Deontic and Dynamic Modality in German and Malay Modal Verbs}

Modal verb is a type of verb known as "modal auxiliary verbs" or "a system of modal verbs" Palmer (1986, p. 1) and in Malay it is called "kata bantu ragam" (KBR). The main use of modal verb is to "related to stance; e.g. the expression of possibility or obligation" Bieber et al. (2004, p. 176). Deontic and dynamic modality refer to events that are not actualized, events that have not taken place but are not merely potential, and may, therefore, be described as 'events modality' Palmer (2001, p. 70). In German, there are potentially six modal verbs: WOLLEN (to want), MÖGEN /MÖCHTEN (to like), SOLLEN (should), KÖNNEN (can), MÜSSEN (must), and $D \ddot{U R F E N}$ (to allow) Palmer (2001, p. 101). To construct a basic modal verb phrase, a minimal of two verbs is required. The conjugated modal verb is placed in the second position; precede the lexical verb while the lexical verb is placed at the end of the phrase in infinitive form.

Malay has relative more modal KBR than German. According to Nik Safiah Karim et al. (2011, p. 369), Malay modal verb (kata bantu ragam-KBR) is verbs that define moods or a person's intention of doing. For example MUNGKIN (maybe), HENDAK/MAHU (want), HARUS/PATUT (should), BOLEH (can), DAPAT (get), MESTI (must), and $E N G G A N$ (refuse). In the construction of Malay KBR phrase, some of the verbs may merge together in a sentence and some can't. For example:

1) May merge together.

a) harus + mahu

b) harus + dapat

c) hesti + mahu

d) mesti + dapat

e) patut + dapat

f) patut + boleh

g) mungkin + boleh

h) mungkin + dapat

Sofia mungkin boleh mengalahkan lawannya dalam pertandingan itu.

'Sofia may be able to defeat her opponent in the competition'.

2) Cannot merge together.

a) hendak + mahu

b) hendak + harus

c) hendak + mesti

d) $m a h u+m e s t i$

e) $m a h u+$ dapat

f) mesti + harus

g) boleh + mesti

h) dapat + hendak

i) hendak + boleh

j) hendak + dapat

k) mahu + hendak

1) mahu + harus

m) $m a h u+b o l e h$

n) boleh + harus

o) dapat + mahu

p) dapat + boleh 
q) enggan + patut

In deontic, the most common type of modality is directives, where we try to get others to do things', Searle (1983, p. 166). 'Müssen' are directives deontic type as it identified permissive and obligative, Palmer (2001, p. 71). In Malay it is commonly translated as 'mesti'.

Du must herein kommen

You must $+2 \mathrm{SG}+$ PRES in. here come

'You must come in'

Awak mesti masuk ke dalam

You + 2SGmust + PRES come in. to inside

'You must come in'

Morphologically, 'should' is the past tense form of 'shall' but the function has been modified from 'must'. Modification deontic is the past tense form of epistemic modal that indicates more tentative and weaker. So the past tense of some deontic modal is used to weaken the force of modality. The German 'sollen' are verbs that differ from 'müssen' which the speaker admits the possibility that the event may not take place, Palmer (2001, p. 73). In Malay there are usually two KBR that are usually translated to 'patut', 'perlu' or 'harus', depending on the content and the force of the modality, Hasmidar Hassan (2009, p. 509). This is seen in Palmer's (2001, pp. 71-73):

Er soll herein kommen, aber wird er nicht.

Dia harus masuk ke dalam tetapi beliau enggan.

'He should come in, but he won't'.

Dynamic modality appears to be having two types of modality namely expressing ability and willingness (abilitive and volitive) which expressed in German modal 'können' (can) and 'dürfen' (to be permitted) and Malay KBR 'boleh', Palmer (2001, p. 101)

Du kannst/darfst den Bleistift be halten

Thou KÖNNEN/DÜRFEN + 2SG + PRESS + IND the pencil keep

'You can keep the pencil'

Awak boleh simpan pensil itu

Thou + 2SGBOLEH + PRESS keep pencil + DEF

'You can keep the pencil'

The German modal verbs 'wollen' and 'mögen' or 'möchten' also fall under this type but usually have much wider meaning that express desire, wishing and wanting. In Malay it is usually translated to 'mahu' or 'hendak'. (Whittle et al., 2011, p. 99):

Sie will morgen kommen

She WOLLEN + 3SG + PRESS tomorrow come

'She wants to come tomorrow'

Dia mahu datang esok

She $+3 \mathrm{SG}+\mathrm{FEM} \mathrm{MAHU}+$ PRESS come tomorrow

This study has two questions concerning the objectives of the study. The questions are; what are the component in German and its contrast to Malay modal verb formation process? How does the modal verb help to show contrast in German and Malay by using Whitman's model (1970). Therefore the objective of the study is to identify and to discuss the contrasted component in the modal verb formation process in German and Malay.

\section{Methodology}

This qualitative study of contrasting German to Malay modal verbs is based on the samples of modal verbs found in 3 editorial columns (January-March) of the Kuala Lumpur German speaking society's magazine "KL-POST" issued in the year of 2012. Content analysis method is applied for this study. The editorial texts will first be read in order to help in understanding the content of the editorial columns. The identified modal verbs will be underlined and translated to English (for understanding purposes) and Malay (for contrastive purposes). 
The verbs will be categorized to find the pair of infinitive verbs that follows in the same sentence. The infinitive verbs will as well be underlined as it is also a part in this sentence formation process. The verbs found will then be contrasted with Malay modal verb forms to obtain the contrastive elements and later to be explicitly discussed. Basically in contrasting a set of languages, the required steps are almost similar in James's Model (1980) and in Whitman's Model (1970). Usually there will be a set of languages to be contrasted and then an element to contrast will be chosen. Whitman's model was used as the main methodology anchoring this study. The study breaks down to a set of component procedures containing 4 steps namely; (1) selecting German as L1 and Malay as L2 and list the formal description of the two languages. (2) Modal verb is chosen to be the contrastive form in this study. (3) The modal verbs is then translated and contrasted to obtain the similarities and differences. From contrasting the modal verbs, the study may show the characteristic of both modal verbs for better understanding which may be used as an alternative explanation in understanding German modal verb formation processes. (4) Lastly, this study will also perform a prediction on the level of difficulty for the contrasted modal verbs. The predictions made for this stage is based on the morphology and semantic elements that surrounds the modal verbs.

According to Littlewood (1989, p. 18) many writers have tried to vary the level of difficulty, in order to provide a systematic basis for predicting learning difficulty. One scheme proposed by Stockwell et al. (1965) is probably one of the best known schemes. To ensure the prediction made is paralleled with CA studies, this study also uses the 'hierarchy of difficulty' by Stockwell et al. (1965). Prator (1967) in Brown (2000) has captured the essence of Stockwell et al., grammatical 'hierarchy of difficulty' and categorized it into six categories.

(1) Level 0-Transfer, No difference or contrast presented between the contrasted languages. The learner can simply transfer a sound, structure, or lexical item from source language (SL) to target language (TL).

(2) Level 1-Coalescence is where two items in SL become coalesced into essential one item in TL.

(3) Level 2-Underdifferentiation, an item in SL is absent in TL. The learners must avoid that item.

(4) Level 3-Reinterpretation, an item that exists in SL is given a new shape or distribution.

(5) Level 4-Overdifferentiation, a new item entirely, bearing any similarity to the native language item and must be learned.

(6) Level 5-Split, one item in SL becomes two or more in the TL and requires the learner to make a new distinction. The 'hierarchy of difficulty' is based mainly on comparing what linguistics choices learners must take in their source language and target language. Therefore, the results of the study will be analyzed based on the contrastive elements made by both German and Malay language and predict the level of difficulty for the learners at the same time.

\section{Results and Discussion}

In all three editorial columns of the $K L-P O S T$ magazine issued from January until March, 11 modal verbs have been found used. In the January issue, only two modal verbs 'möchten' were found used. In the February issue a total of 7 modal verbs were found, 'sollen' was found used 4 times, 'möchten' was used twice and 'wollen' only used once. The use of sollen in the text although it is consider a week obligation, it is consistent with the aim of KL-POST to encourage and urge readers to read the magazine and obtain new information about current issues happening in Malaysia and its neighboring country that might be useful for some readers at their own will without any constrain. In other words, the verbs are intentioned to invite and encourage people, especially German speaker to get involve with the German speaking society's activities and at the same time keep them updated with various information on local culture, cuisine, travelling tips and many more. Indirectly for new German language learners, the language used may be useful as an extra reading material to enhance their German vocabulary skills as the texts are moderate and easy to understand. 
Table 1. Modal verbs used in the editorial column of KL-POST magazine

\begin{tabular}{|c|c|c|c|}
\hline & German Language & English Language & Malay Language \\
\hline S1 & $\begin{array}{l}\text { Ich möchte mich herzlich bei Ihnen } \\
\text { für Ihr Abonnement bedanken. }\end{array}$ & $\begin{array}{l}\text { I would like to thank you for your } \\
\text { subscription. }\end{array}$ & $\begin{array}{l}\text { Saya ingin mengucapkan terima } \\
\text { kasih di atas langganan anda. }\end{array}$ \\
\hline $\mathrm{S} 2$ & $\begin{array}{l}\text { Bedanken möchte ich mich bei } \\
\text { meinem großartigen Team: bei } \\
\text { unseren Gastautoren, unseren } \\
\text { Praktikanten, meinem Stellvertreter } \\
\text { Werner und den aktiven } \\
\text { Redaktionsmitgliedern vor Ort in KL } \\
\text { und in Deutschland. }\end{array}$ & $\begin{array}{l}\text { I would like to thank my great team: } \\
\text { our guest authors, our interns, my } \\
\text { deputy Werner and active editors in } \\
\text { KL and Germany. }\end{array}$ & $\begin{array}{l}\text { Saya ingin mengucapkan terima } \\
\text { kasih kepada kumpulan saya yang } \\
\text { hebat; penulis jemputan, para } \\
\text { pelatih, timbalan saya iaitu Werner } \\
\text { dan editor yang giat aktif di KL dan } \\
\text { Jerman. }\end{array}$ \\
\hline S3 & $\begin{array}{l}\text { Was das für die nächsten } 12 \\
\text { Monate-oder sind es vielleicht sogar } \\
\text { 13?-bedeuten soll, erläutert uns } \\
\text { Andrea Trumm. }\end{array}$ & $\begin{array}{l}\text { What will it mean for the next } 12 \text { or } \\
\text { even } 13 \text { months? Andrea Trumm } \\
\text { explained to us. }\end{array}$ & $\begin{array}{l}\text { Apakah maksudnya untuk bulan ke } \\
12 \text { atau } 13 \text { yang berikutnya? Jelas } \\
\text { Andrea Trumm kepada kami. }\end{array}$ \\
\hline S4 & $\begin{array}{l}\text { Und wer sich als GSSKL-Mitglied } \\
\text { kurzentschlossen an einem } \\
\text { chinesischen Neujahrsessen } \\
\text { beteiligen möchte, sollte nun schnell } \\
\text { auf Seite } 34 \text { weiterblättern, zum } \\
\text { "Gourmet-Geflüster". }\end{array}$ & $\begin{array}{l}\text { GSSKL member, who has decided to } \\
\text { participate in a Chinese New Year } \\
\text { feast, should quickly scroll to page } \\
34 \text { "gourmet whisper'. }\end{array}$ & $\begin{array}{l}\text { Bagi ahli GSSKL yang telah } \\
\text { membuat keputusan untuk menyertai } \\
\text { acara perayaan Tahun Baru Cina, } \\
\text { perlu ke halaman } \\
\text { "Gourmet-Geflüster". }\end{array}$ \\
\hline S5 & $\begin{array}{l}\text { Und wer sich als GSSKL-Mitglied } \\
\text { kurzentschlossen an einem } \\
\text { chinesischen Neujahrsessen } \\
\text { beteiligen möchte, sollte nun schnell } \\
\text { auf Seite } 34 \text { weiterblättern, zum } \\
\text { "Gourmet-Geflüster". }\end{array}$ & $\begin{array}{l}\text { GSSKL member, who has decided to } \\
\text { participate in a Chinese New Year } \\
\text { feast, should quickly scroll to page } \\
34 \text { 'gourmet whisper'. }\end{array}$ & $\begin{array}{l}\text { Ahli GSSKL yang telah membuat } \\
\text { keputusan untuk menyertai acara } \\
\text { perayaan Tahun Baru China, perlu } \\
\text { ke halaman } 34 \text { "Gourmet-Geflüster" }\end{array}$ \\
\hline S6 & $\begin{array}{l}\text { Man sollte dieses Spektakel einmal } \\
\text { mitgemacht haben! }\end{array}$ & $\begin{array}{l}\text { One should have taken part in this } \\
\text { spectacle once. }\end{array}$ & $\begin{array}{l}\text { Anda harus menyertai acara gilang } \\
\text { gemilang ini untuk kesekian kalinya. }\end{array}$ \\
\hline S7 & $\begin{array}{l}\text { Warum sollte man sich bei der } \\
\text { Erkundung neuer, vielleicht auch } \\
\text { ungewöhnlicher Gegenden nicht } \\
\text { Notizen machen und sie in einem } \\
\text { KL-POST-Beitrag zusammenfassen. }\end{array}$ & $\begin{array}{l}\text { Why not take notes while exploring } \\
\text { new and even unusual places and } \\
\text { include them in a KL-POST article. }\end{array}$ & $\begin{array}{l}\text { Kenapa anda tidak menerokai } \\
\text { tempat baharu dan yang luar biasa } \\
\text { serta masukkan ia ke dalam artikel } \\
\text { KL-POST. }\end{array}$ \\
\hline S8 & $\begin{array}{l}\text { Wer Gamelan-Musik liebt und bei } \\
\text { einem Kurs mitmachen möchte, } \\
\text { bekommt auf Seite } 25 \text { Informationen. }\end{array}$ & $\begin{array}{l}\text { For those who love Gamelan music } \\
\text { and want to participate in a course, } \\
\text { you can obtain more information on } \\
\text { page } 25 \text {. }\end{array}$ & $\begin{array}{l}\text { Kepada sesiapa yang menggemari } \\
\text { muzik gamelan dan ingin menyertai } \\
\text { kursus ini, sila dapatkan maklumat } \\
\text { lanjut di halaman } 25 \text {. }\end{array}$ \\
\hline S9 & $\begin{array}{l}\text { Auch wollen wir wieder kritischere } \\
\text { Aspekte unseres ansonsten so } \\
\text { angenehmen Südostasien-Daseins } \\
\text { beleuchten. }\end{array}$ & $\begin{array}{l}\text { Again, we also want to highlight on } \\
\text { more critical aspects apart from our } \\
\text { enjoyable Southeast Asia life. }\end{array}$ & $\begin{array}{l}\text { Sekali lagi, kami ingin menonjolkan } \\
\text { lebih banyak aspek yang kritikal } \\
\text { selain daripada kehidupan yang } \\
\text { menyeronokkan di Asia Tenggara. }\end{array}$ \\
\hline $\mathrm{S} 10$ & $\begin{array}{l}\text { Ich muss schon sagen, das Jahr des } \\
\text { Drachen hat es in sich. }\end{array}$ & $\begin{array}{l}\text { I have to say, the year of the Dragon } \\
\text { has it all. }\end{array}$ & $\begin{array}{l}\text { Saya harus katakan bahawa tahun } \\
\text { naga mempunyai segalanya. }\end{array}$ \\
\hline S11 & $\begin{array}{l}\text { Sollten Sie auf der Suche nach einer } \\
\text { sinnvollen Beschäftigung sein, dann } \\
\text { melden Sie sich bei mir. }\end{array}$ & $\begin{array}{l}\text { Should you be looking for a } \\
\text { meaningful occupation, then get in } \\
\text { touch with me. }\end{array}$ & $\begin{array}{l}\text { Sekiranya anda mengimpikan } \\
\text { pekerjaan yang bermakna, maka } \\
\text { anda perlu hubungi saya. }\end{array}$ \\
\hline
\end{tabular}

Table 1 above shows the modal verbs used in the January, February and March issue of KL-POST. The German language sentences were translated to English for better understanding but only Malay translations were used for modal verbs comparison. The reasons of categorizing the language were also to see the syntactic structure of German and Malay language as well as the process involved in both languages. In S1 and S2, we can see that the noun used for the modal verb 'möchten' is "Ich" (I). The modal verbs are conjugated with the suffix-e and became 'möchte'. A characteristic of Malay modal verbs is that it occurs without affixations (affixless verbs) Nik Safiah Karim (1978, p. 70). This means that Malay modal verbs will stay in its root word even though the modal verb is being used with different noun. In this morphological case, we can predict the 'hierarchy of difficulty'. 
This case fall under level 4-Overdifferentiation, where we can see that the verb conjugation is a new item for Malay learners. German new learners of Malay would find it easier (level 2-Underdifferentiation) as they do not have to memorize any conjugation chart as Malay learners of German do. In this 'hierarchy of difficulty', S4 and S8 is categorizes at level 5-Split. S4 and S8 is where this modal verb 'möchten' get a little bit tricky for the new learners. 'möchten" is an irregular verb and also considers as a strong verb. The irregular verb 'möchten' conjugated by $1^{\text {st }}$ singular person "Ich" and $3^{\text {rd }}$ person singular "er, sie, es" have the same form of suffix-e. Therefore, learners usually faced the confusion, where they commonly make mistake during making distinction between $1^{\text {st }}$ person singular and the $3^{\text {rd }}$ person singular. And more often they conjugate with the suffix-t in a $3^{\text {rd }}$ person singular's irregular verbs even though the verb is an irregular verb, Robe'ah Yusuf (2010).

In S3, the sentence is a question statement. The question statement in German phrase usually uses a $3^{\text {rd }}$ person singular conjugation with the suffix-t. But since 'sollen' is an irregular verb therefore the modal verb 'sollen' conjugated and became similar to the $1^{\text {st }}$ person singular suffix-e. In the 'hierarchy of difficulty' level, S4 and S8 are categorized under level 5, Split. Same thing goes to S5, S6 and S7 which are also in Level 5, Split of the 'hierarchy of difficulty'. This is because the modal verb 'sollen' used here is conjugated with the $3^{\text {rd }}$ person singular 'man' and the irregular verb 'sollen' when conjugated with the $3^{\text {rd }}$ person singular suffix follows the $1^{\text {st }}$ person singular suffix-e. Another distinction in German verb tense is that the verbs also include the sentence tense. 'Sollte' in S5, S6 and S7 is the German (past tense) präteritum form of 'sollen'. This is in contrast with Malay, because in Malay, the form of tense is showed in auxiliary verb ('telah' or 'sudah') (also known as kata bantu aspek) and preceded the lexical verb and therefore the Malay auxiliary verb is not count as a modal verb KBR.

In S9, the modal verb "wollen' is predicted to be at level 4-Overdifferentiation. The modal verb 'wollen' is relatively easy because the word form is the same as the root word and in an infinitive form. The Malay learners would have thought that it is 'not conjugated'. The verb is actually conjugated and the $1^{\text {st }}$ person plural 'wir' that are mentioned in the sentence which make the distinction much easier. In S10, the modal verb 'muss' here is conjugated with the $1^{\text {st }}$ person singular 'ich' from the root modal verb 'müssen'. This sentence is categorizes as level 5-Split, because learners are forced to use the suffix that is not regular with the $1^{\text {st }}$ person singular suffix-e. The modal verb 'müssen' shows strong obligation of must (in Malay 'mesti'). Lastly, in S11 the modal verb 'sollten' is also in a past tense form and conjugated with the $3^{\text {rd }}$ person plural 'Sie' is predicted to be in level 4, Over differentiation. This is due to the reason, although verb with suffix-en is regarded an easy conjugation to learn, Robe'ah Yusuf (2010), but it fall under level 4 because it is a type of conjugation and learners are forced to learn and remember. But the modal verb 'sollten' here shows a past tense form of 'sollen' where it is predicted that learners faced higher level of difficulty.

This study has also found out that there are similarities and differences between German and Malay during the modal verb formation process. For the differences, this study shows that German modal verb must be conjugated according to the noun used while Malay KBR never changes (root word form) even with different noun since conjugation does not exist in Malay. This is where the prediction of difficulties is made. Second is, German modal verb is use in a single form in a single phrase whereas Malay modal verbs may occur together with another modal verb or auxiliary in the same phrase. Thirdly, in a German phrase, the lexical verb is placed at the end of phrase and in an infinitive form. Malay lexical verb on the other hand is placed after the modal verb and may be in the root word form or with affixes. German language shows the sentence tense in its modal verb whereas Malay language expresses its tense by adding an auxiliary verb precedes the modal verb. The most used modal verbs in the text are 'sollen' which expresses possibility or conditional or recommendation which are translated differently in Malay and did just not become a modal verb 'harus' or 'patut' but sometimes also translated to conditional phrase 'if' for example 'sekiranya' or ' $j i k a$ ', depending on the semantic content and when translated to Malay, the verb will no longer be a Malay KBR. Lastly, during the German phrase formation, when there is more compliment phrase or new information that needs to be added in an existing sentence, the new information will be added between the modal verb and the lexical verb. On the contrary, the new information will be added after the lexical verb (preceded modal verb) to form a compliment phrase in a Malay sentence.

Although the typologically of German and Malay is different, there are still similarities that can be found during this contrastive study. The similarities are; German modal verb and Malay KBR carries the same definition of modal verb that define moods and modality. Modal verbs in German and Malay phrases precede lexical verb in a phrase. It is consistent with the second verb placement theory. Thirdly, the German modal verb 'können' used in the text is consistent with the function of dynamic modality that describes factual situation 'can', even when it is translated to Malay 'boleh'. The German modal verb 'müssen' defines the same aim of deontic that expresses 
obligatory of 'must'. In Malay it is translated to 'mesti' and also carrying the same strong obligation as German 'müsen'. Lastly, the German modal verb 'wollen' is likewise defines the same aim as volitive modality that expresses a person's desire. Again in Malay, it could translate to vary forms of Malay KBR such as 'ingin' or 'mahu'.

From the discussion, predictions made are based on morphological difficulty. Syntactically, in the entire German phrase the modal verbs formation process follows the modal + infinitive rule in its second verb placement (Whittle, 2011). The lexical verb is placed at the end of the phrase in an infinitive form. Malay modal form on the other hand, is placed precede the lexical verb in a phrase. Conjugation is also a critical area where new learners often make mistakes (Schmitz, 1991; Yusuf, 2010). The level of difficulty shows that modal verb falls under a very difficult level, which is level 4 and 5. Learners have no choice but to learn this new rule since such rule did not exist in Malay language. Therefore the result in this study is parallel to the result by Schmitz (1991) that due to source language interference, learners may face difficulty and resulting error. The functions of modal verbs are also important especially to translator in order to make sure readers and listener understand the semantic and pragmatic of a certain text. The study by Hasmidar Hassan (2009) is parallel to this study as well.

\section{Conclusion}

This study implicates learners of German in Malaysia who seek alternative explanation to understand German grammar better. The study revealed that by contrasting both languages, learners may see better on how to form a phrase in both languages. German educator may as well take this study as a preparation in their teaching plan where they may provide better explanation for the learners. Apart from that, this study also tries to contribute by promoting more reading material for the German speaking society in Malaysia and as it has been a demand by new learners to have more quality German base reading materials Diedrich (2003). It is best hope that a future study will be conducted to focus on contrasting other German grammar to improve the learners ability to understand and at the same time solve the occurred language problem among Malaysian learners of German.

\section{References}

Bieber et al. (2004). Student Grammar of Spoken and Written English. England: Pearson Education Limited.

Brown, D. (1980). Principles of Language Learning and Teaching (2nd ed.). New Jersey: Prentice Hall.

Brown, D. (2000). Principles of Language Learning and Teaching (4th ed.). San Francisco: Longman.

Coates, J. (1983). The Semantics of the Modal Auxiliaries. London: Croom Helm.

Diedrich, M. (2003). Pengajaran Bahasa Melayu Untuk Penutur Asing (pp. 117-121). Kuala Lumpur: Dewan Bahasa dan Pustaka.

Fisiak, J., Lipińska-Grzegorek, M., \& Zabrocki, T. (1978). An Introductory English-Polish Contrastive Grammar. Warszawa: Państwowe Wydawnictwo Naukowe.

Hassan, H. (2009). Kelestarian Bidang Penterjemahan (pp. 500-512). Persidangan Penterjemahan Antarabangsa Ke-12, 2009. Kuala Lumpur: Persatuan Penterjemahan Malaysia Kuala Lumpur.

James, C. (1980). Contrastive Analysis. Harlow, Essex: Longman.

Karim, N. S. (1978). Bahasa Malaysia Syntax. Some Aspects of Its Standardization. Kuala Lumpur: Dewan Bahasa dan Pustaka.

Karim, N. S., Onn, F. M., Musa, H. H., \& Mahmood, A. H. (2011). Tatabahasa Dewan Edisi Ketiga. Kuala Lumpur: Dewan Bahasa dan Pustaka.

Kendris, C., \& Kendris, T. (2007). 501 Spanish Verbs (6th ed.). New York: Barron's Educational Series, Inc.

Kilic, V. (2013). A Contrastive Study of Turkish and English Modality with Reference to Act Theory. Dialectologia, 10, 1-22.

Koh, Y. C. (2009). The Use of German Articles by Malay Students: An error analysis. Published dissertation for Masters. Kuala Lumpur: University of Malaya.

Lado, R. (1957). Linguistics across Cultures. Ann Arbor, Michigan: University of Michigan Press.

Lee, W. (1968). Thoughts on contrastive linguistics in the context of language teaching. $19^{\text {th }}$ Annual Roundtable (Monograph Series in Language and Linguistics), 21. Washington, D.C.: Georgetown University Press.

Littlewell, W. (1989). Foreign and Second Language Learning. Language-acquisition research and its implications for the classroom (6th ed.). Cambridge: University of Cambridge. 
Palmer, R. (1986). Mood and Modality. Cambridge: Cambridge University Press.

Palmer, R. (2001). Mood and Modality. Cambridge: Cambridge University Press. http://dx.doi.org/10.1017/CBO9781139167178

Prator, C. (1972). Hierarchy of Difficulty. Unpublished classroom lecture, Los Angeles: University of California.

Schmitz, M. (1991). Problems of Source Language Interference with Malay Learners of German. Unpublished thesis for Ph.D. Kuala Lumpur: Universiti of Malaya, Kuala Lumpur.

Searle, R. (1983). Intentionality. Cambridge: Cambridge University Press. http://dx.doi.org/10.1017/CBO9781139173452

Sperber, \& Wilson. (1995). Relevance: Communication and Cognition (2nd ed.). Oxford: Blackwell.

Stockwell, R. P., Bowen, J. D., \& Martin, J. W. (1965). The Grammatical Structures of English and Spanish. Chicago: University of Chicago Press.

Wardaugh, R. (1970). The Contrastive Analysis Hypothesis. TESOL Quarterly, 4, 123-130. http://dx.doi.org/10.2307/3586182

Whitman, R. (1970). Contrastive analysis: Problems and Procedures. Language Learning, 20, 191-197. http://dx.doi.org/10.1111/j.1467-1770.1970.tb00476.x

Whittle, R., Klapper, J., Glökel, K., Dodd, B., \& Eckhard-Black, C. (2011). Modern German Grammar: A practical guide (3rd ed.). Oxon: Routledge.

Yusuf, R. (2010). Analisis Kesilapan Dalam Konjugasi Kata Kerja Regular dan Irregular Bahasa Jerman dalam Kalangan Pelajar Universiti Pendidikan Sultan Idris. Unpublished research report. Tanjung Malim: Universiti Pendidikan Sultan Idris.

\section{Copyrights}

Copyright for this article is retained by the author(s), with first publication rights granted to the journal.

This is an open-access article distributed under the terms and conditions of the Creative Commons Attribution license (http://creativecommons.org/licenses/by/3.0/). 